\title{
Kinerja Pertumbuhan Larva Ikan Depik (Rasbora tawarensis) dengan Tingkat Pemberian Pakan yang Berbeda
}

\author{
Growth Performance of Depik Fish (Rasbora Tawarensis) Larvae with Different \\ Feeding Levels
}

\author{
Siti Komariyah ${ }^{1 *}$, Hilwatun Nisa ${ }^{2}$, Iwan Hasri \\ ${ }^{1}$ Program Studi Budidaya Perairan, Fakultas Pertanian, Universitas Samudra, Aceh \\ ${ }^{2}$ Program Studi Budidaya Perairan, Fakultas Pertanian, Universitas Gajah Putih, Aceh \\ Jl. Prof. Dr. Syarief.Thayeb, Meurandeh, Langsa Lama, Kota Langsa, Aceh 24416 \\ "Korespondensi: Sitikomariyah_adam@yahoo.com
}

\begin{abstract}
ABSTRAK
Ikan Depik (Rasbora tawarensis) adalah salah satu ikan endemik Danau Laut Tawar yang memiliki nilai ekonomis yang tinggi. Namun kini ikan Depik masuk dalam status terancam punah, sehingga perlu dilakukan pelestarian ikan Depik. Salah satu cara yang dapat dilakukan yaitu melalui domestikasi. Untuk melakukan domestikasi diperlukan informasi tentang manajemen pakan yang tepat, salah satunya adalah tingkat pemberian pakan. Penelitian ini dilakukan dengan percobaan menggunakan rancangan acak lengkap dengan empat perlakuan dan tiga pengulangan. Perlakuan pada penelitian ini meliputi: tingkat pemberian pakan 2\% (A), $3 \%$ (B), 5 (C) dan $7 \%$ (D). Parameter yang evalusi adalah pertumbuhan berat mutlak (PMB), pertumbuhan panjang mutlak (PPM), koefisiensi keragaman (KK) dan kualitas air. Analisa data menggunakan analisis ragam dan uji Duncan, sementara data kualitas air dianalisis secara deskripif. Berdasarkan kedua uji tersebut diperoleh hasil bahwa tingkat pemberian pakan terbaik bagi kinerja pertumbuhan ikan Depik adalah 5\%. Kualitas air selama penelitian juga tergolong normal bagi kehidupan ikan Depik.
\end{abstract}

Kata kunci: Pertumbuhan, Rasbora tawarensis, Tingkat Pemberian Pakan.

\begin{abstract}
Depik fish (Rasbora Tawarensis) is one of the endemic fish of Lake Laut Tawar which has high economic value. However, now Depik fish are in endangered status, so it is necessary to conserve Depik fish by one way, namely domestication. To carry out domestication, information is needed about proper feed management, one of which is feeding rate. This research was conducted experimentally using a completely randomized design with 4 treatments and 3 replications. The treatments in this study included: feeding rates of $2 \%(\mathrm{~A}), 3 \%$ (B), 5 (C) and 7\% (D). Parameters observed were absolute weight growth (PMB), absolute length growth (PPM), coefficient of diversity (KK) and water quality. The data analysis used was the F test and Duncan's test, while the water quality data were analyzed descriptively. Based on the two tests, it was found that the best feeding rate for the growth performance of Depik fish larvae was 5\%. Water quality during the study was also considered normal for the life of Depik fish.
\end{abstract}

Keywords: Growth, Rasbora tawarensis, Feeding Rate.

\section{PENDAHULUAN}

Ikan Depik (Rasbora tawarensis) termasuk ke dalam family cyprinid. Ikan ini adalah salah satu ikan endemik
Danau Laut Tawar yang bernilai ekonomis tingg karena sangat diminati masyarakat lokal di sekitar Aceh Tengah terutama suku Gayo. Ikan Depik akan 
diolah menjadi masakan khas suku Gayo yaitu pengat atau dedah. Namun ada juga ikan Depik yang dipasarkan dalam bentuk yang sudah dikeringkan. Tingginya permintaan masyarakat lokal terhadap ikan Depik menyebabkan meningkatnya penangkapan ikan Depik oleh para nelayan. Sementara hasil tangkapan nelayan semakin menurun (Indra, 2015). Akibatnya keberadaan ikan Depik di Danau Laut Tawar semakin terancam. Bahkan berdasarkan status konservasi IUCN Red List, ikan Depik termasuk spesies yang terancam punah (critically endangered) (Lombantobing, 2019).

Adapun cara yang dilakukan untuk menjaga agar kelestarian hidup ikan Depik tetap terjaga adalah dengan melakukan usaha domestikasi. Domestikasi dilakukan dengan cara mengkondisikan lingkungan sesuai dengan sifat biologis dan ekologis ikan tersebut. Domestikasi dapat dilakukan jika informasi tentang kecukupan pakan telah didapat, untuk mempermudah memelihara larva dan mengertahui persentase pakan harian yang sesuai untuk pertumbuhan dan sintasan ikan. Dalam pengembangan ikan Depik, masih mendapatkan beberapa kendala diantaranya mengenai pakan. Oleh karena itu, dengan mengetahui tingkat pemberian pakan yang tepat dan menjaga kualitas air pada ikan Depik merupakan peluang usaha yang baik dilakukan untuk menjaga kelestarian ikan khas ini.

Tingkat pemberian pakan merupakan banyaknya pakan yang diberikan per hari pada ikan yang dipelihara dan biasanya ditunjukkan dalam persen total bobot ikan. Tingkat pemberian pakan adalah salah satu manajemen pemberian pakan yang harus diperhitungkan dengan benar karena sangat menentukan dalam efesiensi penggunaan pakan. Pemberian pakan yang berlebihan dapat mempengaruhi kualitas air dan sebaliknya jika kekurangan pakan akan menghambat pertumbuhan ikan. Beberapa tingkat pemberian pakan terbaik pada ikan family cyprinid adalah 4\% pada ikan Nilem (Pratiwi et al., 2011), 3\% pada ikan Jelawat (Sonavel et al., 2020), 3\% pada ikan Mas (Jasasong et al., 2020). Penelitian ini bertujuan mengevaluasi kinerja pertumbuhan larva ikan Depik yang diberi beberapa tingkat pemberian pakan.

\section{METODE PENELITIAN}

Penelitian ini dilakukan selama 20 hari pada bulan Mei sampai Juni 2017. Penelitian ini bertempat di UPTD Balai Benih Ikan (BBI) Lukup Badak, Kabupaten Aceh Tengah.

Alat yang digunakan dalam penelitian ini yaitu toples dengan volume $5 \mathrm{~L}$, aerasi sebagai penambah oksigen pada air, timbangan digital untuk menimbang bobot tubuh ikan, mm block untuk mengukur panjang ikan, dan alat pengukur kualitas air ( $\mathrm{pH}$ dan $\mathrm{DO}$ meter). Sementara bahan yang digunakan adalah larva ikan Depik berumur 2 minggu serta pakan pellet komersil dengan kadar protein $48 \%$

.Rancangan penelitian yang digunakan adalah RAL (Rancangan Acak Lengkap) dengan empat perlakuan dan tiga pengulangan. Menurut Schneider et al. (2005) tingkat pemberian pakan berkisar antara 2-8\%, sehingga perlakuan dalam penelitian ini adalah 2\% (perlakuan A), 3\% (perlakuan B), $5 \%$ (pelakuan C) dan 7\% (perlakuan D).

Sebelum digunakan, wadah dibersihan dan disterilisasi. Wadah diisi air hingga bervolume 3 liter. Serta ditambahkan aerasi untuk meningkatkan kadar DO dalam air. Ikan uji yang digunakan dalam penelitian ini berasal dari penetasan telur yang diperoleh dari alam (Danau Laut Tawar), yaitu diambil dari dedesen (perangkap ikan Depik). Hal ini dilakukan karena saat ini pemijahan ikan Depik juga masih dalam tahap pengembangan, sehingga ketersediaan ikan Depik di Balai juga masih terbatas. Telur ikan Depik ditetaskan di BBI Lukup Badak Aceh Tengah. Larva yang digunakan sebagai 
ikan uji berumur 2 minggu dengan padat tebar 7 ekor/liter.

Pakan yang diberikan berupa pakan pelet komersil yang diremahkan hingga berbentuk crumble dengan ukuran sesuai bukaan mulut larva ikan Depik. Sebelum pakan diberikan, terlebih dahulu pakan ditimbang sesuai dengan perlakuan. Pada hari ke-10 pakan dihitung dan ditimbang kembali berdasarkan data sampling bobot larva pada hari ke-10. Frekuensi pemberian pakan pada larva yaitu $4 \mathrm{kali} / \mathrm{hari}$, yaitu pada pagi, siang, sore dan malam hari.

Pengelolaan kualitas air dilakukan agar kualitas air tetap terjaga sesuai dengan kebutuhan hidup ikan Depik. Pengelolaan kualitas air yang dilakukan adalah penyiponan setiap pagi hari sebelum pemberian pakan dan pergantian air sebanyak $70 \%$ dari seluruh volume air. Pergantian air juga dilakukan setiap hari karena pakan yang diberikan berbentuk crumble sehingga cepat mencemari air pemeliharaan larva ikan Depik.

Pengambilan data dilakukan setiap 10 hari sekali dimulai dari hari ke 0 sebagai data awal penelitian, kemudian hari ke-10 dan ke-20. Pengukuran panjang menggunakan kertas milimeter Blok dan penimbangan berat menggunakan timbangan digital. Sampel yang diukur dan ditimbang sebanyak 10 ekor yang diambil secara acak. Pengambilan data kualitas air meliputi $\mathrm{pH}$, suhu, DO (oksigen terlarut), TDS (padatan terlarut) dan konduktivitas dilakukan setiap pengambilan sampel ikan.

Parameter yang diamati pada penelitian ini adalah pertumbuhan berat mutlak (PBM) di hitung berdasarkan rumus Effendi (1979).

Keterangan :

$$
\mathrm{PBM}=\mathrm{Wt}-\mathrm{Wo}
$$

PBM : Pertumbuhan berat mutlak (g)

Wt : Berat rata-rata ikan pada akhir penelitian $(\mathrm{g})$

Wo : Berat rata-rata ikan pada awal penelitian $(\mathrm{g})$

Perhitungan pertumbuhan panjang mutlak (PPM) dihitung dengan rumus Effendie (1979) yaitu sebagai berikut :

$$
\mathrm{PPM}=\mathrm{Pt}-\mathrm{Po}
$$

Keterangan :

PPM : Pertumbuhan panjang mutlak (mm)

$\mathrm{Pt} \quad$ : Panjang rata-rata ikan pada akhir penelitian $(\mathrm{mm})$

Po : Panjang rata-rata ikan pada awal penelitian (mm)

Keragaman panjang dinyatakan dalam koefesien keragaman panjang. Koefesien ini merupakan persentase dari simpangan baku panjang ikan sampel terhadap nilai tengahnya. Penghitungan KK menggunakan rumus Steel dan Torrie (1982), yaitu:

$$
\mathrm{KK}=\left(\frac{S}{Y}\right) \times 100 \%
$$

Keterangan :

$$
\begin{array}{ll}
\text { KK } & \text { : Koefesien keragaman } \\
\mathrm{S} & \text { : Simpangan baku } \\
\mathrm{Y} & \text { : Rata-rata sampel }
\end{array}
$$

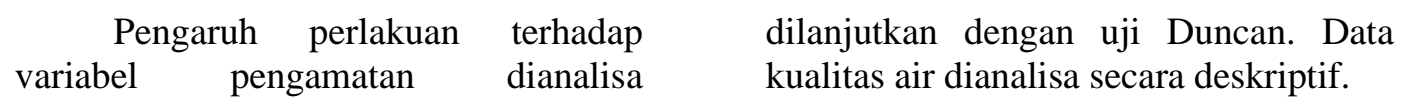
menggunakan analisis ragam (uji $\mathrm{F}$ ) pada derajat bebas 0,05 . Apabila data berpengaruh nyata $(\mathrm{P}<0,05)$ maka 
Pola pertumbuhan ikan Depik dapat diamati dari pertambahan panjang dan berat ikan. Berdasarkan hasil pertumbuhan berat dari penelitian larva ikan Depik selama 20 hari yaitu pada setiap perlakuan, nilai tertinggi terdapat pada perlakuan $\mathrm{C}$ yaitu $0,09 \mathrm{~g}$, sedangkan nilai rata-rata terendah terdapat pada perlakuan A yaitu $0,06 \mathrm{~g}$. Kenaikan pertumbuhan yang signifikan terjadi pada hari ke-0 sampai hari ke-10, hal ini ditandai dengan kemiringan grafik yang curam. Sementara pada hari ke-10 hingga hari ke-20 pertambahan berat larva ikan Depik tidak terlalu signifikan, yang ditandai dengan kemiringan grafik yang landai (Gambar 1).

Sama halnya dengan pertumbuhan berat, pada pertumbuhan panjang larva ikan Depik tertinggi juga terjadi pada perlakukan $\mathrm{C}$ dan terendah pada perlakuan A. Namun, penambahan panjang larva ikan Depik dari hari ke-0 hingga hari ke-20 hampir konsisten, hal ini ditandai dengan kemiringan grafik yang hampir sama pada hari ke-0 hingga ke-10 dan hari ke-10 hingga hari ke-20 (Gambar 2).
Pada penelitian ini, pertumbuhan panjang larva ikan Depik lebih besar dibandingkan pertumbuhan beratnya. Pola pertumbuhan seperti ini disebut pertumbuhan alometrik negatif. Hal ini sesuai dengan pernyataan Fuadi et al. (2016), pertumbuhan alometrik negative adalah pertumbuhan panjang lebih cepat dari pertumbuhan berat. Pola pertumbuhan pada ikan Depik ini juga terjadi pak ikan Jelawat (Leptobarbus hoeveni) (Sonavel et al., 2020).

Hasil analisis varian (Anova) dapat dilihat pada Tabel 1. Berdasarkan uji Anova, pemberian tingkat pakan yang berbeda berpengaruh signifikan $(\mathrm{P}<0,05)$ terhadap pertumbuhan berat mutlak (PBM), pertumbuhan panjang mutlak (PPM) dan koefisien keragaman (KK) larva ikan Depik. Berdasarkan uji Duncan, PBM pada C (FR 5\%) berbeda nyata dengan perlakuaan lainnya, sementara A,B dan D tidak berbeda nyata. PPM pada perlakuan A berbeda nyata dengan perlakuan lainnya, sementara B,C dan D tidak berbeda nyata. Serta KK pada A berbeda nyata dengan $\mathrm{D}$, namun tidak berbeda nyata dengan perlakuaan lainnya.

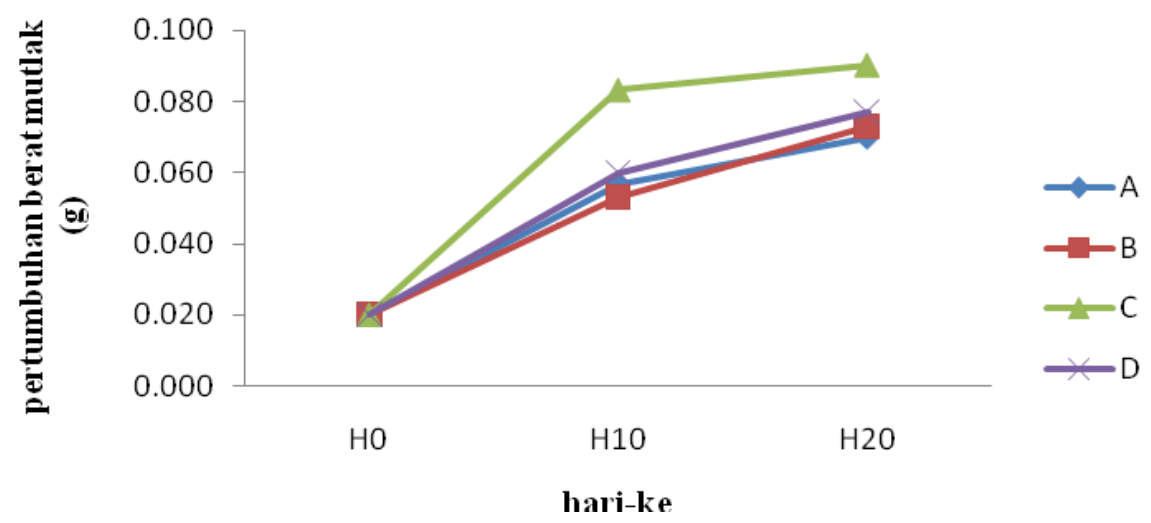

Gambar 1. Grafik pertumbuhan berat larva ikan Depik (Rasbora tawarensis) yang diberi tingkat pakan yang berbeda (Keterangan: A. Perlakuan 2\%, B. Perlakuan 3\%, C. Perlakuan 5\%, D. Perlakuan 7\%) 


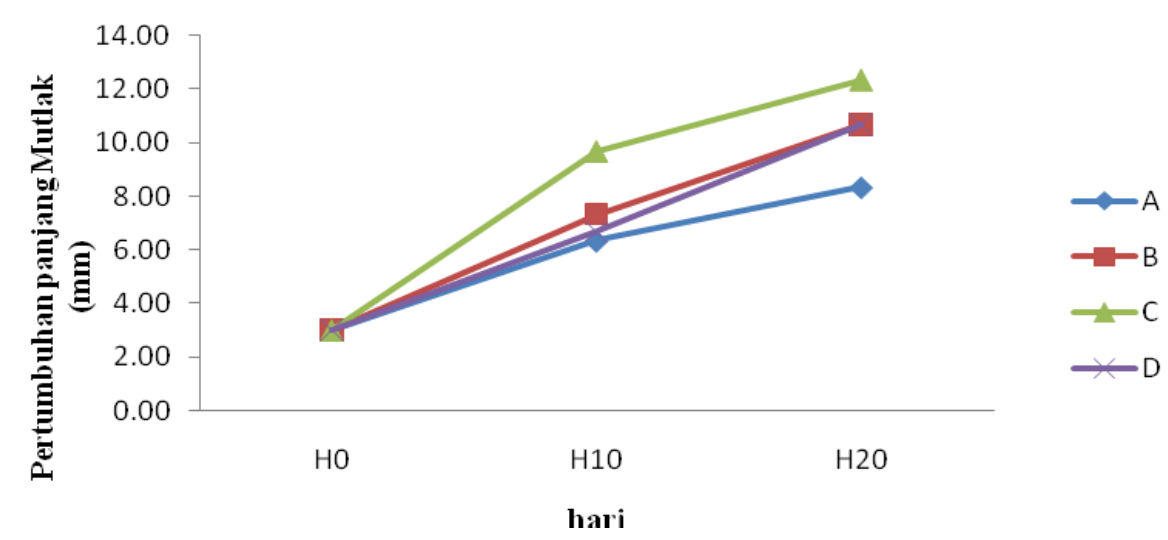

Gambar 3. Grafik pertumbuhan panjang larva ikan Depik (Rasbora tawarensis) yang diberi tingkat pakan yang berbeda. Keterangan: A. Perlakuan 2\%, B. Perlakuan 3\%, C. Perlakuan 5\%, D. Perlakuan 7\%

Tabel 1. Pertumbuhan berat mutlak (PBM), pertumbuhan panjang mutlak (PPM) dan koefesien keragaman (KK) panjang larva ikan Depik (Rasbora tawarensis) dengan pemberian tingkat pemberian pakan yang berbeda.

\begin{tabular}{lcccc}
\hline \multirow{2}{*}{ Parameter } & \multicolumn{4}{c}{ Perlakuan } \\
\cline { 2 - 5 } & $\mathrm{A}(2 \%)$ & $\mathrm{B}(3 \%)$ & $\mathrm{C}(5 \%)$ & $\mathrm{D}(7 \%)$ \\
\hline PBM $(\mathrm{g})$ & $0,50 \pm 0,00^{\mathrm{a}}$ & $0,53 \pm 0,05^{\mathrm{a}}$ & $0,76 \pm 0,05^{\mathrm{b}}$ & $0,56 \pm 0,05^{\mathrm{a}}$ \\
PPM (mm) & $5,33 \pm 1,52^{\mathrm{a}}$ & $7,67 \pm 0,57^{\mathrm{b}}$ & $9,33 \pm 0,57^{\mathrm{b}}$ & $7,67 \pm 0,57^{\mathrm{b}}$ \\
KK & $12,1 \pm 5,39^{\mathrm{b}}$ & $9,71 \pm 5,39^{\mathrm{ab}}$ & $5,82 \pm 1,05^{\mathrm{b}}$ & $2,84 \pm 2,27^{\mathrm{a}}$
\end{tabular}

Keterangan : Huruf yang berbeda pada baris yang sama menunjukkan pengaruh yang berbeda nyata $(\mathrm{P}<0,05)$ nilai yang tertera merupakan nilai rata-rata dan simpangan baku.

Berdasarkan hasil penelitian menunjukkan bahwa baik pertumbuhan berat maupun panjang mutlak larva ikan depik meningkat seiring dengan peningkatan tingkat pemberian pakan dari $2 \%$ sampai $5 \%$, kemudian menurun jika tingkat pemberian pakan ditingkatkan menjadi 7\%. Dengan demikian bahwa tingkat pemberian pakan yang optimum untuk larva ikan depik adalah 5\% dari biomassa perhari. Hal ini menunjukkan bahwa tingkat pemberian pakan 5\% telah sesuai dengan kebutuhan tubuh larva ikan Depik, isi lambung dan tahapan daya cerna ikan Depik sehingga dapat memberikan hasil yang optimum terhadap pertumbuhan ikan Depik. Hal ini sesuai dengan pernyataan Kompiang (2000), bahwa tingkat pemberian pakan merupakan salah satu faktor yang sangat berpengaruh terhadap pertumbuhan berat ikan karena tingkat pemberian pakan adalah persentase pakan yang dibutuhkan oleh ikan perharinya, dan sebagai pemasok energi untuk meningkatkan pertumbuhan berat ikan. Subandiyono et al. (2009) juga menyatakan bahwa pertumbuhan terjadi jika ada energi yang berlebih dari asupan pakan setelah kebutuhan energi minimum (untuk kehidupan pokok) sudah terpenuhi seperti respirasi, aktivitas berenang, proses metabolisme dan maintenance.

Lebih rendahnya pertumbuhan berat dan panjang pada perlakuan A (2\%) dibanding perlakuan lainnya diduga karena jumlah pakan yang diberikan belum memenuhi kebutuhan larva ikan Depik untuk tumbuh secara optimal. Serta lebih rendahnya pertumbuhan pada D (7\%) daripada C (5\%) diduga karena jumlah pakan yang diberikan berlebihan, walaupun pada dasarnya larva membutuhan tingkat pemberian pakan yang lebih tinggi, namun jika berlebihan juga berdampak 
terhadap pertumbuhan. Hal ini sesuai dengan pernyatan Zonneveld et al. (1991), bahwa tingkat pemberian pakan dipengaruhi oleh jenis dan umur ikan atau ukuran ikan. Ikan-ikan yang lebih muda atau kecil memerlukan tingkat pemberian pakan harian yang lebih tinggi untuk pertumbuhan, tetapi harus sesuai dengan daya cerna ikan itu sendiri, jika tingkat pemberian pakan harian tidak sesuai atau terlalu tinggi maka akan berpengaruh bagi pertumbuhannya.

Hasil yang diperoleh dari pemeliharaan selama 20 hari menunjukkan bahwa nilai koefesien keragaman panjang tertinggi terdapat pada perlakuan A yaitu dengan nilai 12,1. Sedangkan nilai koefesien keragaman terendah terdapat pada perlakuan D dengan nilai 2,84 . Keseragaman panjang ditandai dengan nilai KK yang rendah. Sehingga dari hasil penelitian ini menunjukkan ukuran panjang ikan pada perlakuan D paling seragam dari pada perlakuan lainnya. Di dalam pertumbuhan ikan semakin seragam ukuran ikan maka semakin baik pula pertumbuhannya (Mattjik dan Sumertajaya, 2002). Rendahnya keseragaman panjang pada perlakuan A diduga karena rendahnya jumlah pakan yang diberikan, sehingga terjadi persaingan perebutan makanan di dalam akuarium. Akibatnya asupan pakan dalam wadah pemeliharaan tidak merata. Asupan pakan yang tidak merasa menyebabkan pertumbuhan yang tidak seragam. Hal ini didukung oleh penyataan Sunarto dan Sabariah (2009), bahwa jumlah pakan yang terlalu sedikit akan mengakibatkan pertumbuhan ikan lambat dan akan terjadi persaingan pakan yang mengakibatkan ukuran ikan bervariasi.

Hasil pengamatan data kualitas air dapat dilihat pada Tabel 2. Kisaran kualitas air selama penelitian adalah DO $8,5-8,9 \mathrm{mg} /$ liter, suhu $20,6-22,8^{\circ} \mathrm{C}$, TDS 85 - 86 ppm, dan konduktivitas $143-154 \mu \mathrm{s}$. Kisaran tersebut masih dalam kategori normal bagi kehidupan larva ikan Depik. Hasil penelitian Komariyah dan Afrizal (2019), kisaran DO selama pemeliharaan ikan depik lebih rendah daripada penelitian ini, yaitu 5,52 - 5,64 mg/liter, kisaran suhu $20,77-21,40{ }^{\circ} \mathrm{C}$ dan $\mathrm{pH} 6,90-7,15$. Semakin tinggi nilai konduktifitas (sesuai dengan nilai yang telah ditentukan) semakin baik kondisi media air. Sesuai dengan Lesmana (2004) Nilai $\mathrm{pH}$ yang baik untuk ikan berkisar antara $7-8,6$ dan nilai konduktifitas oftimal antara $20-1500 \mu \mathrm{s}$.

Tabel 2. Pengukuran parameter kualitas air media pemeliharaan larva ikan Depik selama penelitian

\begin{tabular}{ccccccc}
\hline No & Perlakuan & $\begin{array}{c}\text { DO } \\
(\mathrm{mg} / \mathrm{l})\end{array}$ & $\begin{array}{c}\text { Suhu } \\
\left({ }^{\circ} \mathrm{C}\right)\end{array}$ & $\begin{array}{c}\text { TDS } \\
(\mathrm{ppm})\end{array}$ & $\mathrm{pH}$ & $\begin{array}{c}\text { Konduktivitas } \\
(\mu \mathrm{s})\end{array}$ \\
\hline 1 & $\mathrm{~A}(2 \%)$ & 8,7 & 22,8 & 86 & 8,1 & 145 \\
2 & $\mathrm{~B}(3 \%)$ & 8,7 & 22,8 & 85 & 8,1 & 143 \\
3 & $\mathrm{C}(5 \%)$ & 8,5 & 21,6 & 86 & 7,8 & 145 \\
4 & $\mathrm{D}(7 \%)$ & 8,9 & 20,6 & 86 & 8,4 & 154 \\
\hline
\end{tabular}

\section{KESIMPULAN DAN SARAN}

Berdasarkan hasil penelitian yang di lakukan selama 20 hari dapat disimpulkan bahwa tingkat pemberian pakan untuk ikan depik terbaik adalah pada tingkat pemberian pakan 5\%. Untuk penelitian selanjutnya disarankan untuk dilakukan penelitian berkaitan dengan tingkat pemberian pakan ikan Depik pada stadia yang berbeda.

\section{DAFTAR PUSTAKA}

$\begin{array}{ccr}\text { Effendi,MI.1997. } & \text { Metode } & \text { Biologi } \\ \text { Perikanan } & \text { Yayasan } & \text { Dewi } \\ \text { Sri.Bogor. 163 Hal. } & \end{array}$


Fuadi, Z. Dewiyanti I, dan Purnawan S. 2016. Hubungan Panjang Berat Ikan yang Tertangkap di Krueng Simpoe, Kabupaten Bireun, Aceh. Jurnal Ilmiah Mahasiswa Kelautan dan Perikanan Unsyiah, 1(1): $169-176$

Indra. 2015. Kajian Kondisi Perikanan Di Danau Laut Tawar Aceh Tengah. Agrisep, 16 (2): 62-96.

Jasansong K, Salindeho IRN, Kreckhoff RL. 2020. Pertumbuhan benih ikan mas, Cyprinus carpio, yang diberi pakan dengan dosis berbeda pada kolam pekarangan dengan sistim resirkulasi. Budidaya Perairan,8(1): 1-7

Komariyah, S dan Afrizal, FY. 2019. Pertumbuhan Benih Ikan Depik (Rasbora tawarensis) yang Diberi Berbagai Pakan Alami. LIMNOTEK Perairan darat Tropis di Indonesia, 26 (1): 4753.

Kompiang, A. 2000. Peningkatan Reproduksi dan Pertumbuhan Ikan Nila (Oreochromis niloticus) di Indonesia. $1 \mathrm{Hal}$

Lumbantobing, D. 2019. Rasbora tawarensis. The IUCN Red List of Threatened Species 2019: e.T19316A2204120. http://dx.doi.org/10.2305/IUCN.U K.20192.RLTS.T19316A2204120.en

Lesmana, 2004. Kualitas Air Untuk Ikan Hias Air Tawar. Penebar Swadaya. Jakarta, 88 Halaman.

Mattjik, AA. Sumertajaya M 2002. Perancangan Percobaan dengan Aplikasi SAS dan Minitab. IPB Press, Bogor.

Pratiwi, Rostika R, Dhahiyat Y. 2011. Pengaruh Tingkat Pemberian Pakan terhadap Laju Pertumbuhan dan Deposisi Logam Berat pada Ikan Nilem di Karamba Jaring Apung Waduk Ir. H. Djuanda. Jurnal akuatika, 11 (2).

Sonavel NP, Sapto D, Diantari R. 2020. Pengaruh Tingkat Pemberian Pakan Buatan Terhadap Performa Ikan Jelawat (Leptobarbus hoeveni). Jurnal Sains Teknologi Akuakultur, 3 (1) : 52-65.

Subandiyono, dan Sri Astuti., Nutrisi Ikan. Universitas Ponogoro. 2009

Sunarto dan Sabariah. 2009. Pemberian Pakan Buatan dengan Dosis Berbeda Terhadap Pertumbuhan dan Konsumsi Pakan Benih Ikan Semah (Tor douronensis) dalam Upaya Domestikasi. Jurnal Aquakultur Indonesia. Fakultas Perikanan dan Ilmu Kelautan Universitas Muhammadiyah Pontianak.

Steel, A. \& Torrie, K. 1982. Manual of Salmonid Farming. Black Well Science, London.

Zonneveld, NE. A Huisman, dan JH. Boon. 1991. Prinsip-prinsip Budidaya Ikan. PT. Gramedia Pustaka Utama, Jakarta, 336 hal. 
